University of Nebraska - Lincoln

DigitalCommons@University of Nebraska - Lincoln

Papers in the Earth and Atmospheric Sciences

Earth and Atmospheric Sciences, Department

2008

\title{
A 700-Year History of Groundwater Recharge in the Drylands of NW China
}

John B. Gates

University of Nebraska-Lincoln, jgates2@unl.edu

W. Mike Edmunds

Oxford University

Jinzhu Ma

Lanzhou University

Paul R. Sheppard

University of Arizona

Follow this and additional works at: https://digitalcommons.unl.edu/geosciencefacpub

Part of the Earth Sciences Commons

Gates, John B.; Edmunds, W. Mike; Ma, Jinzhu; and Sheppard, Paul R., "A 700-Year History of Groundwater Recharge in the Drylands of NW China" (2008). Papers in the Earth and Atmospheric Sciences. 270. https://digitalcommons.unl.edu/geosciencefacpub/270

This Article is brought to you for free and open access by the Earth and Atmospheric Sciences, Department of at DigitalCommons@University of Nebraska - Lincoln. It has been accepted for inclusion in Papers in the Earth and Atmospheric Sciences by an authorized administrator of DigitalCommons@University of Nebraska - Lincoln. 
Published in The Holocene 18:7 (2008), pp. 1,045-1,054; doi: 10.1177/0959683608095575.

Copyright (C) 2008 Sage Publications. Used by permission.

Submitted June 15, 2007; revised manuscript accepted March 6, 2008.

\title{
A 700-Year History of Groundwater Recharge in the Drylands of NW China
}

\author{
John B. Gates, ${ }^{1}$ W. Mike Edmunds, ${ }^{2}$ Jinzhu $\mathrm{Ma}^{3}$ and Paul R. Sheppard ${ }^{4}$
}

\author{
1. University of Nebraska-Lincoln, Lincoln, Nebraska, USA; jgates2@unl.edu \\ 2. Oxford Centre for Water Research, Oxford University, Oxford, UK \\ 3. Center for Arid Environment and Palaeoclimate Research, Key Laboratory of Western China's Environmental System, \\ Lanzhou University, Lanzhou, China \\ 4. Laboratory of Tree-Ring Research, University of Arizona, Tucson, Arizona, USA
}

\begin{abstract}
A 700-year semi-quantitative history of diffuse groundwater recharge in the Badain Jaran Desert (Inner Mongolia) is proposed on the basis of solute data from multiple unsaturated zone groundwater profiles using mass balance of chloride to establish recharge rates and profile chronologies. Four relatively humid (1330-1430, 1500-1620, 1700-1780 and 1950$1990)$ and three relatively arid phases (1430-1500, 1620-1700 and 1900-1950) are discernable across the profiles. The recharge history broadly reflects multidecadal to centurial timescale precipitation changes in the northern Tibetan Plateau and suggests that variations in East Asian Summer Monsoon intensity affect desert recharge rates. Uncertainties in the records owing to assumptions about the $\mathrm{Cl}$ inputs are examined by comparing deterministic and stochastic $\mathrm{Cl}$ input scenarios. Such records are valuable for assessing spatial aspects of climate changes in the region, as well as for informing sustainable water resource management strategies for northwestern China's drylands.
\end{abstract}

Keywords: Groundwater, Unsaturated zone, Chloride, Badain Jaran, Recharge, Monsoon, China, Late Holocene.

\section{Introduction}

Variations in atmospheric moisture conditions over the last millennium in northwest China have been inferred from a wide range of proxies including ice cores (Yao and Thompson, 1991; Thompson et al., 1995; Thompson et al., 1997), tree rings (Sheppard et al., 2004; Shao et al., 2005), lake sediment cores (Zhang et al., 2003; Herzschuh et al., 2006) and historical documents (Zhang and Crowley, 1989; Gong and Hameed, 1991). While some general trends are discernable across the records, they also emphasize the spatial complexity of moisture trends in the region resulting from the interplay of multiple climatic influences including the East Asian monsoon, westerly cyclonic fronts and northerly continental air masses, and from effects of the Tibetan Plateau's topography on atmospheric circulation patterns (Feng et al., 2006). As such, expansion of the geographic coverage of palaeohumidity records is needed for elucidation of spatial dimensions of climatic variability in the region.

One related question is to what extent observed climatic shifts persist across the region's moisture gradient from the Tibetan Plateau to the drylands of the Alashan Plateau. Millennial-scale trends in moisture conditions in the Badain Jaran Desert (Figure 1), situated to the northeast of the Tibetan Plateau and near the current northern boundary of the East Asian monsoon (Ding and Chan, 2005), based on lake sediment cores and geomorphologic evidence suggests climatic shifts approximately synchronous with surrounding areas, including a Holocene humidity 'optimum' approximately 10,000-6,000 yr BP (Shi et al., 2002; Yang and Williams, 2003; Zhang et al., 2004; An et al., 2006; Gao et al., 2006). However, shorter-term fluctuations associated with intermittent strengthening and weakening of the monsoon may be more localized in effect, for which high-resolution comparisons over shorter timescales are currently lacking. In water-scarce areas of northwestern China, this information has added importance for understanding contemporary climatic trends in order to inform sustainable water management and development strategies.

This paper reports on a study of temporal trends in $30 \mathrm{~m}$ percolation (i.e., potential groundwater recharge) in the Ba- 


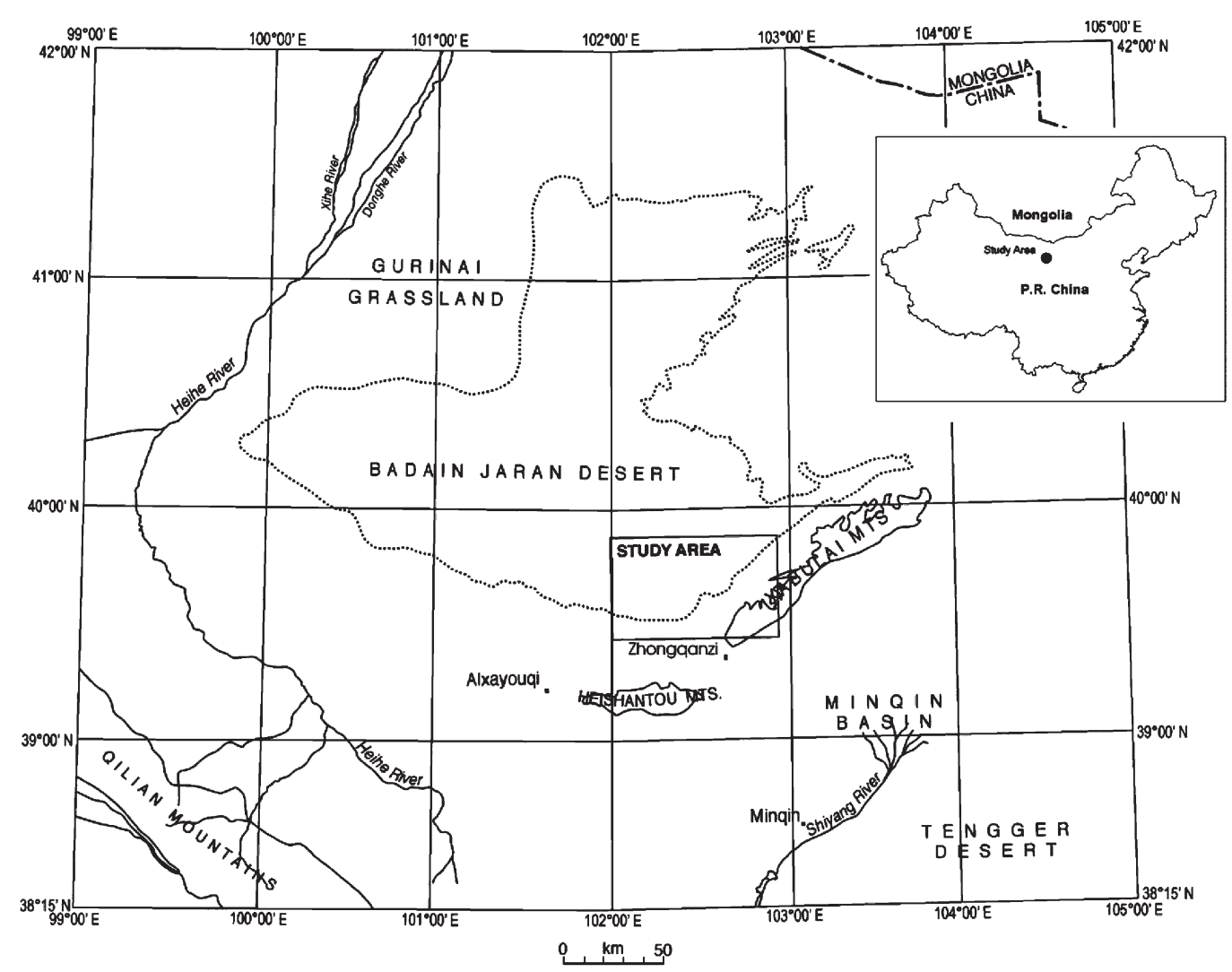

Figure 1. Map of the study area

dain Jaran Desert resulting from climatic forcing. The study is based on solute concentrations in pore moisture of partially saturated sands, which may serve as a semi-quantitative proxy for precipitation. The aims of the paper are to (1) derive a time series of potential recharge in the Badain Jaran Desert using $\mathrm{Cl}$ mass balance and (2) to assess the relationship to precipitation elsewhere in the region based on other proxy measurements. The deep unsaturated zone profile presented in this study is analysed in connection with several previously published profiles from the southeastern Badain Jaran and builds upon this earlier work (Ma et al., 2003; Ma and Edmunds, 2006; Gates et al., 2008).

\section{The unsaturated zone as an archive of recharge history and environmental change}

\section{Background}

The unsaturated zone refers to the portion of the subsurface that is above the level of the water-table and is partially saturated, ie, contains both air and liquid water in the pore spaces between sediment grains. In arid regions only a small percentage of water that has reached the land surface as precipitation infiltrates deep enough to reach the water-table, thereby becoming groundwater recharge. Most of the moisture which falls as precipitation is evaporated at or near the land surface because of the strong excess of evaporation over precipitation. Transpiration by root structures also serves to remove moisture from the subsurface. Water that infiltrates below a near-surface zone of evapotranspiration (sometimes referred to as the active mixing zone or root zone) is no longer subject to high rates of evapotranspiration and is termed potential recharge. In arid areas such infiltration events tend to occur intermittently and are associated with temporary excess of precipitation over evapotranspiration associated with intense or prolonged storm events. Unless climatic perturbations alter the energy balance of the unsaturated zone, potential recharge continues to percolate downward at a rate driven primarily by the balance between matric forces and gravity, eventually becoming recharge once it reaches the water-table. Upward flux can occur in both liquid and vapour phases in response to energy gradients in the unsaturated zone, but rates are generally less than $0.1 \mathrm{~mm} / \mathrm{yr}$ (Ross, 1984; Walvoord et al., 2002b; Scanlon et al., 2003). This is within measurement error of most recharge studies but must be carefully considered in cases of extremely low recharge.

\section{Chloride as a tracer}

By removing a percentage of water and leaving behind any solutes, evapotranspiration concentrates solutes into the remaining moisture. As a result, an inert tracer such as $\mathrm{Cl}$ can serve as an indicator of the degree of enrichment because of water loss, provided that no other sources are present in the unsaturated zone. $\mathrm{Cl}$ is perhaps the only element that is conservative in its behavior in the unsaturated zone, considering that it is without significant involvement in redox reactions, solute complexation or mineral adsorption (Hem, 1985). $\mathrm{Cl}$ may be added physically through inputs from geological sources such as evaporites and saline marine or continental formation waters, or impeded relative to water in low porosity sediments (Feth, 1981; Lehmann et al., 2003). The lack of solid-phase $\mathrm{Cl}$ sources and low-permeability sediments at the study site allows this analysis to proceed on the assumption that all $\mathrm{Cl}$ in the pore moisture is atmospherically derived and it is transmitted through the unsaturated zone at the same rate as water.

In such cases, the mass balance of $\mathrm{Cl}$ in the unsaturated zone can be formulated as

$$
P C_{P}=R C_{R}
$$

where $P$ is the mean precipitation rate $(\mathrm{L} / \mathrm{T})$ and $C_{P}$ is the 
mean $\mathrm{Cl}$ concentration in precipitation $\left(\mathrm{M} / \mathrm{L}^{3}\right)$ over the period of record, $R$ is recharge rate $(\mathrm{L} / \mathrm{T})$, and $C_{R}$ is measured $\mathrm{Cl}$ concentration of potentially recharging pore waters $\left(\mathrm{M} / \mathrm{L}^{3}\right)$ (Allison and Hughes, 1978). The left-hand side of the equation represents total $\mathrm{Cl}$ inputs, and must be adjusted if any other sources of $\mathrm{Cl}$ than rainfall solutes are present. In particular, inputs by dry deposition have been shown to represent more than $50 \%$ of $\mathrm{Cl}$ inputs in some desert areas and must be taken into account (Dettinger, 1989; Selaolo et al., 1994). This equation represents the quasi-steady state form of the mass balance such that all parameters are formulated as constants, and is the most frequently used form because more detailed $\mathrm{Cl}$ input data are usually unavailable. In this case, recharge is inversely proportional to pore water $\mathrm{Cl}$ concentration $C_{r}$. A more general formulation is given by Ginn and Murphy (1997) that allows for transient precipitation, evapotranspiration and/ or $\mathrm{Cl}$ deposition for applications where these inputs are well characterized.

In cases of relatively homogeneous sandy or silty unsaturated zone conditions, water flow below the mixing zone often closely approximates that of piston flow, i.e., vertical infiltration with younger water uniformly displacing older water downward (Zimmermann et al., 1967). In such cases, vertical fluctuations in chemical composition of pore waters can serve as an indicator of environmental conditions during recharge. A chronology for the profile can be established by comparing cumulative $\mathrm{Cl}$ from the surface to a given depth $z_{i}$ with the rate of $\mathrm{Cl}$ influx,

$$
t=\frac{1}{P C_{P}} \int_{0}^{z_{i}} \theta(z) C_{r}(z) \mathrm{d} z
$$

where $t$ represents residence time, $\theta$ is volumetric moisture content, and $z$ is depth (Tyler et al., 1996). This chronology is independent of any physical measurements of hydraulic head or water movement.

The piston flow assumption is crucial to the application of this model because significant bypass flow can alter cumulative $\mathrm{Cl}$ totals. As a result, unsaturated zones with properties that promote macropore or fracture flow are usually not suitable for archive reconstruction. While bypass flow in sandy materials has been demonstrated in the shallow mixing zone and at high moisture contents, it has not been observed in deep unsaturated sands of low or moderate moisture contents. The piston flow assumption can also be violated by the direction of unsaturated zone flow, which can diverge from vertically downward in some cases. For example, modelling studies have suggested that net water flux in deep unsaturated zones in some locations in the Southwestern USA, where water ages maybe measured in thousands of years, may currently be upward through the vapour phase as the hydrological system continues to adjust to the modern arid climate (Walvoord et al., 2002a). Also, lateral components to unsaturated flow have been documented in applied tracer studies in sloping terrain (McCord and Stephens, 1987; Scanlon, 2000).

The temporal resolution of unsaturated zone records is dependent upon vertical sampling density, but may also be limited by the persistence time of solute signals. Processes of diffusion and dispersion have a dampening effect on climate signals over time, the rate of which depends on several factors, including the magnitude of solute variation, moisture content, recharge rate and physical properties of the unsaturated zone solid phase Cook et al. (1992) estimate that the persistence time of a 20-yr climatic event (ie, solute peak or trough) would be approximately 100 years given a recharge rate of $10 \mathrm{~mm} /$ $\mathrm{yr}$, and 1000 years for a recharge rate of $100 \mathrm{~mm} / \mathrm{yr}$ and moisture content of 5\% (V/V). However, Ginn and Murphy (1997) suggest that this model may overestimate the degree of mix- ing in unsaturated zones with low moisture contents and cite a range of field and experimental evidence for the insignificance of mixing processes in deep unsaturated zones of low moisture content and percent clay content. A full discussion of the method's limitations is given by Edmunds and Tyler (2002).

\section{Previous Studies}

Research into the unsaturated zone as an archive of palaeoclimatic information has spanned more than two decades in the hydrogeology literature. Drawing from earlier work on $\mathrm{Cl}$ as a conservative tracer in groundwater (Eriksson and Khunakasem, 1969), studies in Cyprus provided the first unsaturated zone profiles interpreted in terms of recharge history, and demonstrated a temporal relationship between Cl-based recharge rates and precipitation (Edmunds and Walton, 1980; Kitching et al., 1980). These studies also suggested the prevalence of piston-flow in the unsaturated zone, which has subsequently been investigated in many locations using the bombpulse tritium peak as an independent chronometer (Nativ et al., 1995; Gaye and Edmunds, 1996; Lin and Wei, 2006).

Case studies of unsaturated zone palaeoenvironmental records have been undertaken in a wide range of conditions and geo-graphic regions (see for example Jolly et al. (1989); Bromley et al. (1997); de Vries et al. (2000); Joshi and Maule (2000); Edmunds and Gaye (1994); Scanlon (1991)), most of which have been based on $\mathrm{Cl}$. Additional tracers have been used to help constrain $\mathrm{Cl}$ input functions $\left({ }^{36} \mathrm{Cl}\right.$ and $\mathrm{Br}$; for example Phillips (1994)), or to provide complementary proxies for environmental processes $\left({ }^{3} \mathrm{H}, \delta^{2} \mathrm{H}, \delta^{18} \mathrm{O}\right.$; for example de Vries et al. (2000)). Unsaturated zone records have extended back as far as the Pleistocene in the case of deep boreholes from Yucca Mountain in the southwestern USA (Tyler et al., 1996). In several studies, archives have compared favourably with other monitoring data or closely related climate proxies. Reconstructions from the Cyprus profiles correlate well with recorded annual rainfall over a 30-yr time period (Edmunds and Walton, 1980). Results from profiles in northern Senegal correlate well with river flow records for the Senegal River from 1900 through 1990, and with reconstructions of Lake Chad water levels over a 500-yr time span (Edmunds et al., 1992). However, unsaturated zone records do not represent local longterm rainfall records as well as Senegal River discharge rates, suggesting that such integrated records may be more representative proxies of regional conditions.

Unsaturated zone profiles from the southeastern Badain Jaran Desert have recently shown to be promising for palaeoclimate reconstructions. For example, Ma and Edmunds (2006) and Ma et al. (2003) note a correspondence between unsaturated zone records and net accumulation in the Guliya ice core. The multi-profile study of Gates et al. (2008) has demonstrated the commonality of recharge histories for a wide range of geographical settings within the desert, supporting the assumption that piston flow is prevalent and small-scale spatial variability is minor. These results and the current paper represent the first published unsaturated zone palaeoenvironment records in China.

\section{Methods}

A $30 \mathrm{~m}$ unsaturated zone profile (field code SWDA) was collected from a large sand dune in the vicinity of Lake Sayin Wusu in the southeastern Badain Jaran $\left(39^{\circ} 34.37^{\prime} \mathrm{N}\right.$; $\left.102^{\circ} 20.17^{\prime} \mathrm{E}\right)$. The dune is sparsely vegetated with grasses and shrubs (primarily Artemisia sphaerocephala and Psammochloa mongolica) which, based on preliminary field reconnaissance, occur in densities typically less than 1 plant $/ \mathrm{m}^{2}$. An elevated location relative to nearby lakes (60 $\mathrm{m}$ above Lake Sayin Wusu) was selected to avoid any effects of moisture or solutes from the 


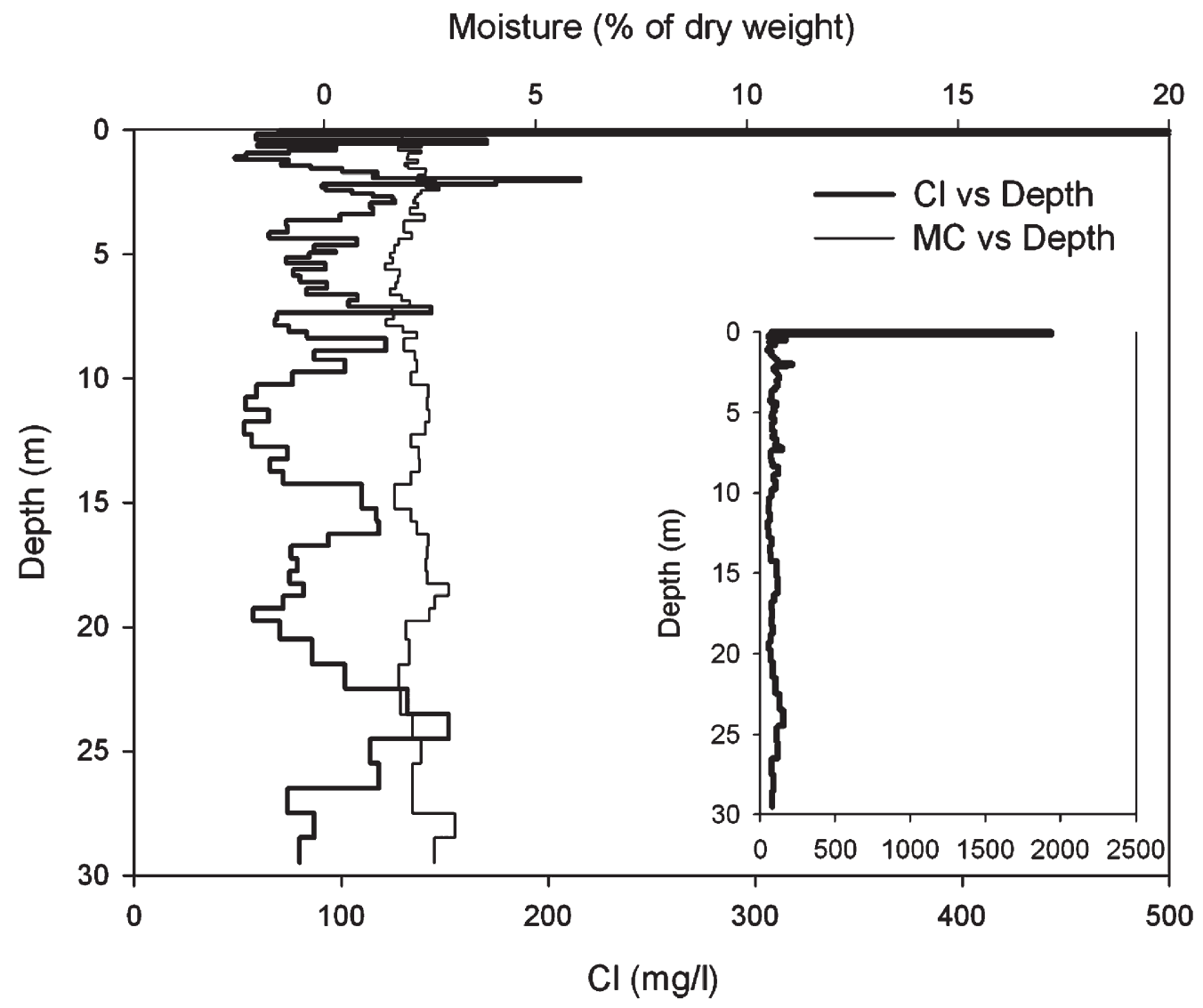

Figure 2. Depth profile of $\mathrm{Cl}$ and moisture content

water-table and the remote location ensures that no cultivation has occurred at the site. Samples were collected using a hollowstem hand auger (Dormer Engineering, Australia) with interchangeable $1.5 \mathrm{~m}$ aluminum rods. Bulk sediment samples of approximately $500 \mathrm{~g}$ were collected at intervals ranging from 0.13 to $1.0 \mathrm{~m}$, with sampling intervals coarsening with depth. Samples were homogenized over the sampled interval and immediately sealed in polyethylene bags to prevent evaporation.

Unsaturated zone moisture was extracted by elutriating $50 \mathrm{~g}$ of moist sediments with $30 \mathrm{ml}$ of deionized water, then centrifuging and filtering supernatant at $0.45 \mu \mathrm{m}$. Major anion concentrations of elutriated samples were analysed using ion chromatography (Dionex DX-500) at the Oxford University Centre for the Environment, and soil moisture contents were determined gravimetrically after drying for $24 \mathrm{~h}$ at $110^{\circ} \mathrm{C}$. Analytical precision was 3\% of concentration and the detection limit was approximately $0.1 \mathrm{mg} / 1$ for elutriates.

\section{Results}

\section{Overview}

The unsaturated zone at the profile site consists entirely of unconsolidated Quaternary aeolian sands which comprise the Badain Jaran dune field. Sand grain sizes in the profile have a mean diameter of $0.22 \mathrm{~mm}$ and follow a bimodal size distribution similar to previous results for the area (Jäkel, 2002). Land cover at the site is very sparse, with only a few shrubs (Artemisia sphaerocephala) in the vicinity (nearest shrub $\sim 3 \mathrm{~m}$ away from the profile site).

Moisture contents in the profile are generally low $(1-3 \%$ of dry weight; Figure 2). In most locations in the dune field, visible soil moisture occurs from approximately $20-40 \mathrm{~cm}$ below surface. Elevated near-surface moisture contents of $4.9 \%$ are recorded in the SWDA profile owing to a rain event that occurred one day prior to sampling. In this case the wetting front had penetrated $45 \mathrm{~mm}$, and the underlying dry layer $(0.58 \%$ dry weight from $45 \mathrm{~mm}$ to $300 \mathrm{~mm}$ ) represents surficial dry conditions that have not yet been affected by the wetting front. Below $300 \mathrm{~mm}$ moisture con-tents are relatively uniform with a depth-weighted mean value of $2.1 \%$ (standard deviation $0.33 \%)$.

Chloride concentrations in the profile range from 1,938 $\mathrm{mg} / \mathrm{l}$ in the near-surface peak, to as low as $49 \mathrm{mg} / \mathrm{l}$ (for the interval 1.125-1.25 m; Figure 2), with a depth-weighted mean of $91 \mathrm{mg} / 1$ below $300 \mathrm{~mm}$. The peak at 45-300 mm represents $\mathrm{Cl}$ which had been heavily enriched because of intense evaporation at the surface and corresponds to $1,526 \mathrm{mg} / \mathrm{m}^{2} \mathrm{Cl}$. The $\mathrm{Cl}$ concentration of the surface moisture $(70 \mathrm{mg} / \mathrm{l})$ is relatively close to the mean concentration for the profile. The second highest concentration of $\mathrm{Cl}$ in the profile $(215 \mathrm{mg} / \mathrm{l})$ occurs at $2.0 \mathrm{~m}$ below surface. Smaller peaks in $\mathrm{Cl}$ occur at approximately $7.6 \mathrm{~m}, 16.8 \mathrm{~m}$ and $25.5 \mathrm{~m}$.

\section{Steady-state parameters for recharge and chronology derivation}

A long-term average recharge rate represented by the profile can be calculated with Equation (1) and estimates of average $\mathrm{Cl}$ input rates. Annual precipitation records are available for several stations surrounding the study area, and show a general trend of increasing aridity from south (Hexi Corridor) to north (towards the Gobi Desert). Zhongqanzi is the nearest station to the study site (approximately $20 \mathrm{~km}$ to the southeast) and is likely to be the most representative of meteorological conditions in the southeastern Badain Jaran, with a mean 


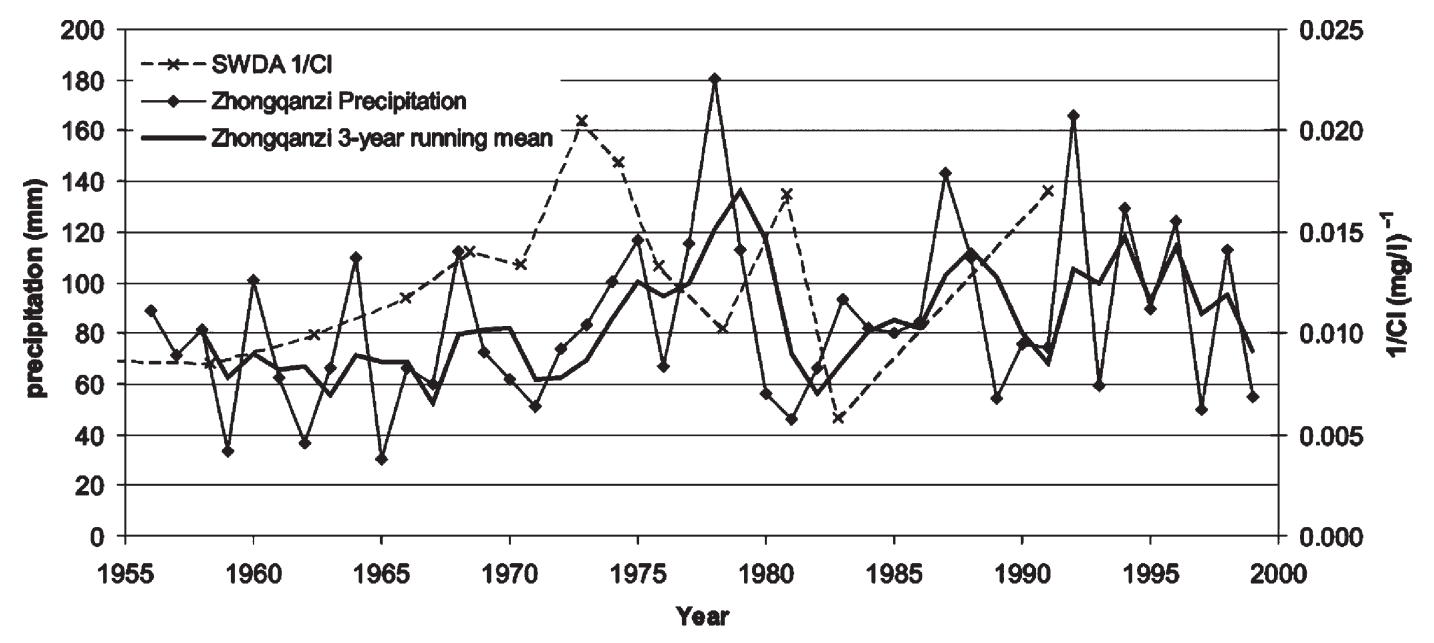

Figure 3. Zhongqanzi precipitation and SWDA $1 / \mathrm{Cl}$

annual precipitation of $84 \mathrm{~mm} / \mathrm{yr}$ over the period 1956 to 1999 (Figure 3). The standard deviation of $33 \mathrm{~mm} / \mathrm{yr}$ over this period illustrates the high degree of variability in interannual precipitation in the desert; the wettest year on record $(181 \mathrm{~mm}$ in 1978) is six times the driest (30 $\mathrm{mm}$ in 1965).

Records of solute concentrations in rainfall are sparse in most areas and are unavailable for much of China. Even where extensive records are available this can be a difficult parameter to estimate because of high spatial and temporal variability. For example, Goni et al. (2001) found that solute concentrations tended to decrease over the course of the rainy season in the Sahel region of Africa owing to decreasing importance of localized dust sources over time. The estimate of $\mathrm{Cl}$ content in Badain Jaran rain-fall of $1.5 \mathrm{mg} / 1$ measured by Ma and Edmunds (2006) is based on mean precipitation from 2001 to 2002 in Zhonquanzi and one large storm in 1999 (approximately $50 \mathrm{~mm}$ ), which represented the majority of precipitation for the calendar year. This is similar to volume-weighted average $\mathrm{Cl}$ concentration in rainfall for three rural locations in the vicinity of $\mathrm{Xi}^{\prime}$ an $\left(34^{\circ} 14^{\prime} \mathrm{N}\right.$; $\left.108^{\circ} 57^{\prime} \mathrm{E}\right)$, the nearest available extended monitoring records $(1.7 \mathrm{mg} / 1$ from 2000 to 2005; EANET, 2006). The value of $1.5 \mathrm{mg} / \mathrm{l}$ is adopted as the best available estimate for $\mathrm{Cl}$ concentration in rainfall in the study area. It is assumed that this estimate includes inputs resulting from dry deposition because it is based on measurements from bulk rainfall samplers, which tend to incorporate inputs from dry deposition.

An average recharge rate of $1.35 \mathrm{~mm} / \mathrm{yr}$ is calculated based on these deposition values and a depth-weighted mean of 93 $\mathrm{mg} / \mathrm{l} \mathrm{Cl}$ for pore water below the surface peak. This represent $\sim 1 \%$ of mean annual precipitation and is similar to the previous estimates for the study area (Ma and Edmunds, 2006; Gates et al., 2008). The deposition values are also used to establish a chronology for the profile with Equation (2), which results in a total $\mathrm{Cl}$ accumulation time of 681 years for the profile.

\section{1/Cl time series}

Trends in the time series of $1 / \mathrm{Cl}$ serve as an indicator of relative moisture changes over time for the case that $1 / \mathrm{Cl}$ is proportional to recharge (i.e., assuming constant $\mathrm{Cl}$ inputs; Figure 4). Periods of above-average recharge in SWDA include AD 1510-1640, 1700-1775, 1820-1830, 1880-1900, and much of 1960 -present, which peaks at $0.021 / \mathrm{mg}$ in 1973. A smaller peak is apparent in $\sim 1377$, which represents a slight rise above the average $1 / \mathrm{Cl}$ value of 0.012 prior to an extended dry phase from 1380 to 1550 . Other periods of low recharge include AD $1640-1710,1780-1820,1830-1850$ and 1890-1960.
These general trends are common to most unsaturated zone profiles from the Badain Jaran Desert, including Profile SW1 from Ma and Edmunds (2006), which represents a 1300-yr record. Peaks between 1350 and 1400, 1500 and 1600, 1700 and 1800 , and $\sim 1900$ are common to both SW1 and SWDA. Trends from 1800 to 1950 in these records are also reflected in many of the shorter unsaturated zone records described in Gates et al. (2008), in particular profiles SWSA05-16 and SWSC0510. There is disagreement in the records, however, for the period 1950-1990, which is shown to be relatively wet in SWDA, BA and SA, but dry in SW1 and BA2. Based on comparison of SWDA and the most densely sampled profile from Ma and Edmunds (2006), a qualitative 700-yr recharge history is proposed for the Badain Jaran (Figure 4), with four centurial-scale high-recharge phases and three low-recharge phases apparent. The period 1785-1890 por-trays moderate recharge overall with shorter timescale fluctuations approximately in phase between the two profiles, and is grouped together and categorized as variable (Figure 4) since the timing of decadal-scale fluctuations cannot be reliably discerned because of uncertainties in $\mathrm{Cl}$ inputs (see section 'Recharge history reconstruction' below). The period 1950-1990 is categorized as having above-average recharge based on weight of evidence from all published profiles, though it is recognized that there is disagreement between the records including portrayal of belowaverage recharge in SW1.

\section{Comparison of the unsaturated zone with other proxies}

The Badain Jaran unsaturated zone records portray some strong similarities to trends in the Juniper tree ring record from Dulan, northeastern Qinhai (Sheppard et al., 2004; Figure 5) on multi-decadal to centurial timescales. In both cases, the wettest periods within the records occur at approximately AD 1380, 1580, 1750 and intermittently between 1830 and 1900. The SWDA and the tree-ring records also both indicate above-average wetness since AD 1950. This modern wet period is especially evident in the tree-ring record when the ringwidth data are standardized conservatively in order to fully preserve their low-frequency variation (Sheppard et al., 1997), in which case the peak portrays the highest humidity over the 700 -yr period as in the SWDA profile. Periods of relative aridity also correspond well, though with some exceptions including the period 1700-1730, which appears relatively arid in the tree-ring record and relatively humid to in the unsaturated zone record. Overall, the Dulan record (30-yr running mean) 


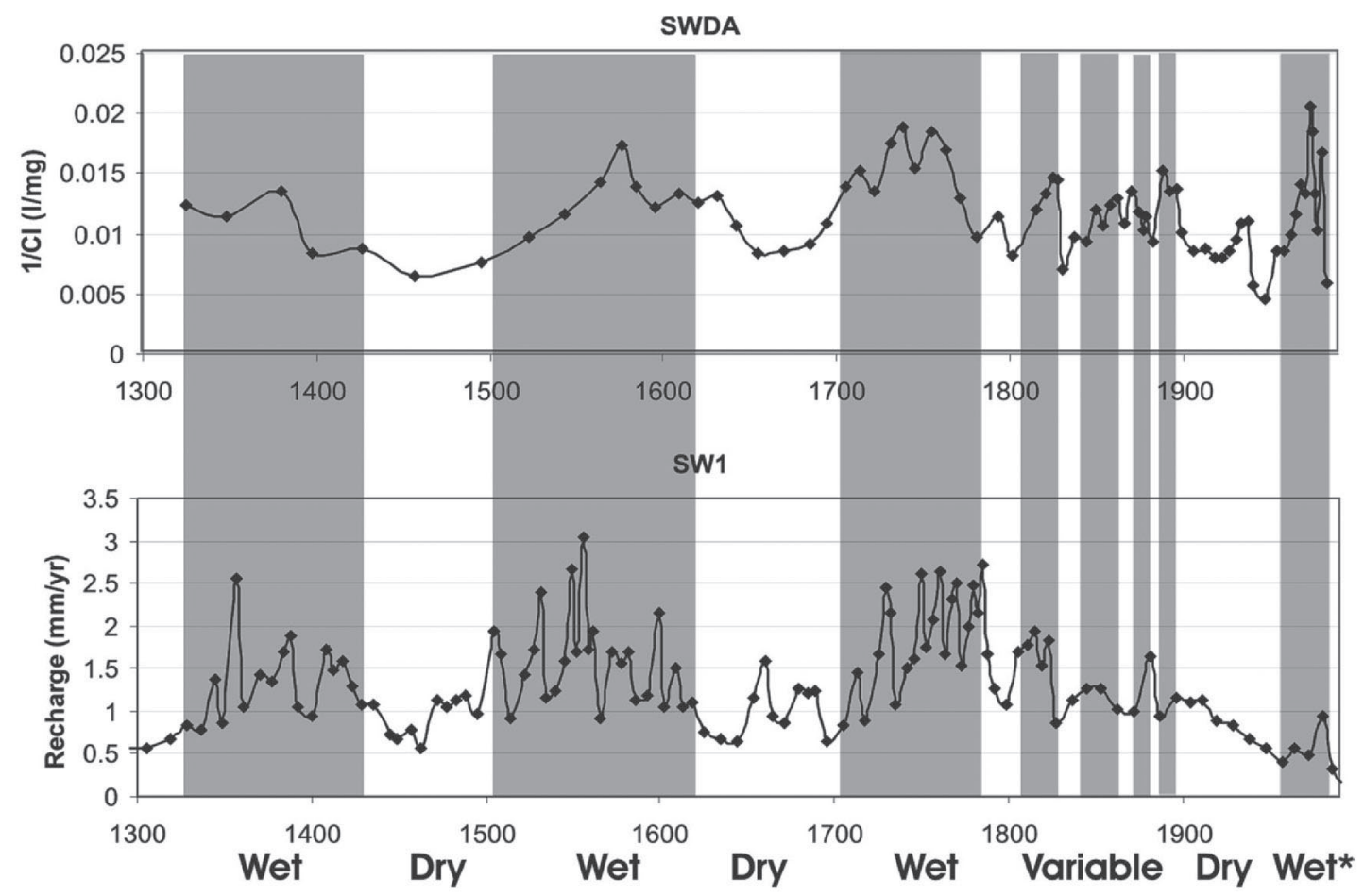

Figure 4. Badain Jaran unsaturated zone recharge history

and profile SWDA have a cross-correlation coefficient of +0.26 for the period 1324-1992.

The relationship with ice accumulation in the northern Tibetan Plateau cores is not as strong, though some parallels are apparent. For the period 1750 to the present, the unsaturated zone reflects some general patterns portrayed in the $\mathrm{Gu}-$ liya and Dunde cores, though the Guliya record is the better match with the unsaturated zone in certain periods, for example 1900-1950, despite the greater distance from the Badain Jaran Desert (2000 and $500 \mathrm{~km}$, respectively; 30-yr running means shown in Figure 5; Yau, 1991; Thompson et al., $1995,1997)$. In contrast, between approximately AD 1600 (the terminus of the Dunde ice accumulation record) and 1750, the unsaturated zone record is better reflected in the Dunde core, both portraying a relative dry phase around 1650. Similar century-scale moisture patterns from 1300 to the present are also reflected in $\delta^{18} \mathrm{O}$ values of carbonate in fine-grained sediments in Lake Qinhai, which are used as a proxy for evaporation/ precipitation ratios by Zhang et al. (2003).

Within the Badain Jaran, the 160-yr high-resolution sediment core of Herzschuh et al. (2006) from Lake Baoritelegai is the only proxy record available for comparison on a similar timescale. Moisture conditions in the Lake Baoritelegai record do not reflect those in the unsaturated zone, and are in fact anti-correlated for much of the period. The reasons for this are unclear, though uncertainty in the $\mathrm{Cl}$ input function may play a role at this timescale (see uncertainty analysis below). In addition, a limited comparison between $1 / \mathrm{Cl}$ and rainfall in the study area can be made using the $40-y r$ record of precipitation from Zhonqanzi (Figure 3). Variations in the unsaturated zone record reflect the 3-yr moving average of rainfall totals reasonably well, apart from a divergence from 1970 to 1974. The period 1992 to the present cannot be assessed because of the solutes currently stored in the near-surface mixing zone. The resolution of the $\mathrm{Cl}$ data is coarse at this scale because the $50-y r$ record is stored within the top $2 \mathrm{~m}$ of the profile.

Parallels can also be made between the recharge history and Chinese historical records. Notably, the century-scale fluc- tuations in the unsaturated zone records appear remarkably similar to the Beijing wetness/dryness index from 1450 to the present based on written precipitation records (Hameed et al., 1983). Also, the two periods within the last 500 years for which the most Chinese counties were affected by drought (16001650 and 1800-1820) correspond to periods of low recharge in the Badain Jaran with the exception of 1815-1827 (State Meteorological Administration, 1981; after Zhang and Crowley, 1989). These periods represent relatively cool/dry phases throughout much of China associated with weakening of the East Asian monsoon, suggesting that variations in recharge may also be largely driven by monsoon variability.

\section{Recharge history reconstruction}

The derivation of quantitative recharge history based on unsaturated zone chloride is subject to numerous complications. For one, both the recharge chronology and the recharge rates themselves are dependent upon the characterization of the history of $\mathrm{Cl}$ input fluxes. Calculated recharge rates and timescales are very sensitive to specified input fluxes (1:1 ratio of percent error in $\mathrm{Cl}$ flux and percent error in timescale). As in most unsaturated zone $\mathrm{Cl}$ mass balance applications, the chronology presented in the section ' $1 / \mathrm{Cl}$ time series' above assumes that modern $\mathrm{Cl}$ deposition rates are constant over time. While this tends to give reliable results for long-term mean recharge (Equation (1)), time-varying recharge histories based upon this assumption may be more uncertain in arid regions with high interannual variability in precipitation. Nonetheless, the constant influx assumption is often made because of lack of historical deposition data.

In order to test the sensitivity of the SWDA recharge history to uncertainties in the input function, three model simulations are compared. For all three simulations the potential effects of mixing are ignored and thus reconstructed temporal variability in recharge history should be treated as a lower bound estimate of actual temporal variability. In the first simulation, a recharge history is constructed for the quasi-steady 


\title{
Widespread Chinese droughts
}

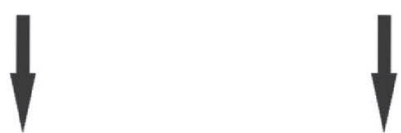

Dulan Juniper tree
ring precip
$(\mathrm{mm} / \mathrm{yr})$

\author{
Dunde lce Core \\ annual net \\ accumulation \\ $(\mathrm{mm} / \mathrm{yr})$
}

Guliya Ice Core
annual net
accumulation
(mm/yr)
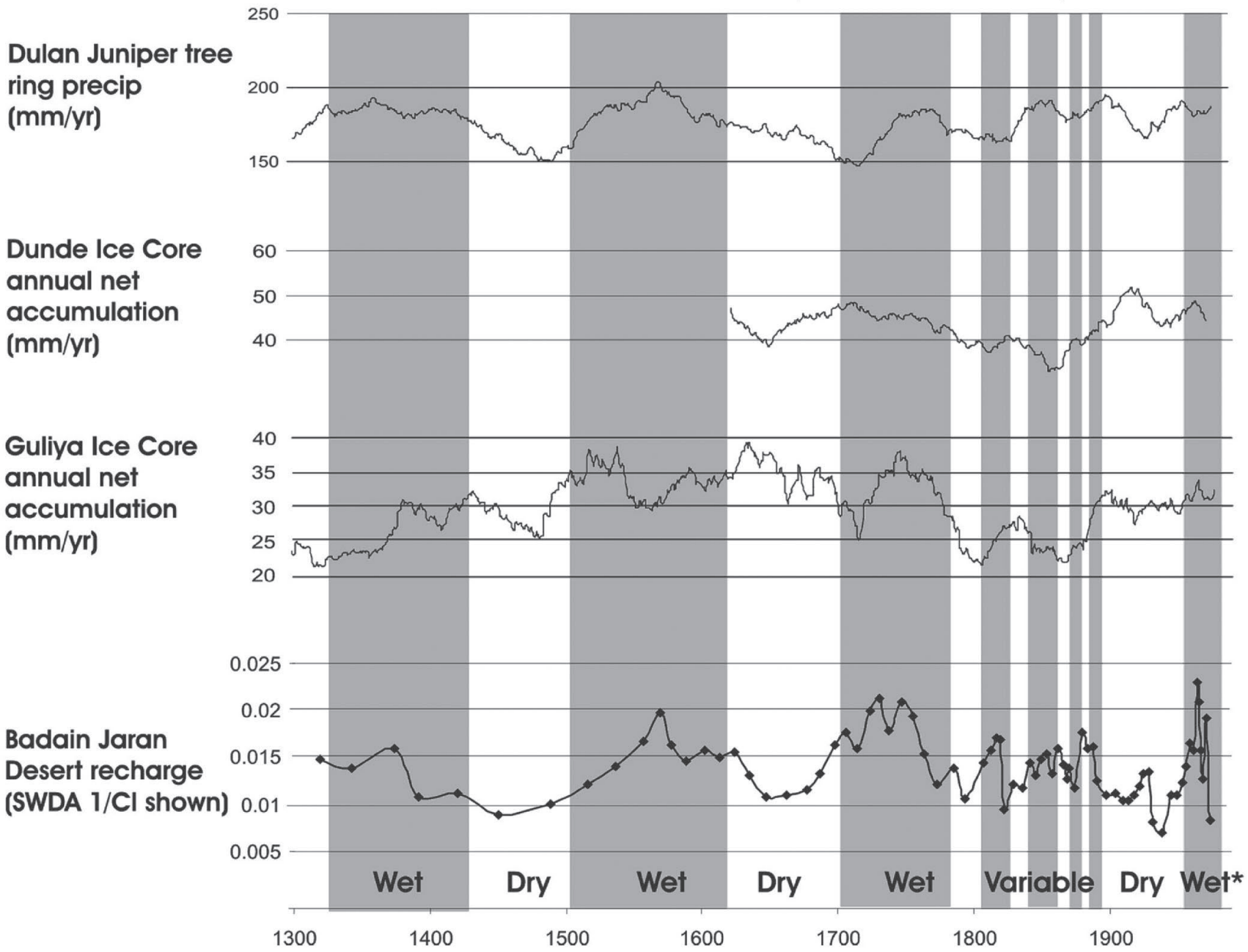

Figure 5. Multiple proxy comparison of humidity histories

state case assuming a constant $\mathrm{Cl}$ input function (see the section 'Steady-state parameters for recharge and chronology derivation' above). The chronology for this case is identical to the one presented in the section ' $1 / \mathrm{Cl}$ time series' for $1 / \mathrm{Cl}$ and recharge rates and determined by Equation (1). In the second simulation, the chronology and recharge rates are calculated using time-varying $\mathrm{Cl}$ inputs estimated from independent palaeoclimate data. For this case, the tree-ring record of Sheppard et al. (2004) is selected to drive inputs because of the good correlation with the $1 / \mathrm{Cl}$ record and because both proxies are closely related to soil moisture availability. In this simulation the Dulan tree ring rainfall record drives the $\mathrm{Cl}$ input function using the assumptions that Badain Jaran rainfall is proportional to Dulan rainfall over time. This simulation uses a numerical implementation of the generalized chloride mass balance model (Ginn and Murphy, 1997). The third simulation is a stochastic estimate of uncertainty for the constant $\mathrm{Cl}$ input function case, which is used to assess the statistical significance of reconstructed temporal fluctuations.

Comparison of simulations 1 and 2 illustrates the effects of the $\mathrm{Cl}$ input scenarios on recharge history (Figure 6). The most notable differences are alterations in peak shapes and to a lesser degree peak magnitude, and some shifts in the chronology (up to 20 years in some cases). The divergence in the two records appears greatest early in the record (near the base of the profile). However, the general trends in moisture based on $1 / \mathrm{Cl}$ (Figure 4) are maintained in both cases. The average recharge rate in the time-varying case is marginally higher $(+0.08 \mathrm{~mm} / \mathrm{yr})$ owing to slightly lower mean rainfall than the constant case (overall cross-correlation +0.70 ).

Simulation 3 consists of a Monte-Carlo representation of variable $\mathrm{Cl}$ inputs and resulting recharge histories based on mean and standard deviation of the Zhongqanzi rainfall record. This approach is chosen over traditional error propagation techniques because of the complication that uncertainties in $\mathrm{Cl}$ input can affect both chronology and recharge magnitude. Simulation con-ditions assume that (i) annual $\mathrm{Cl}$ mass deposition is linearly related to annual precipitation amount and (ii) interannual rainfall variability observed from 1956 to the present (i.e., standard deviation) is representative of interannual variability over the entire $700-y r$ period of record. The number of Monte Carlo iterations $(n=5000)$ was chosen such that the simulation means for each sample closely reproduce the results of simulation 1 . The $2 \sigma$ error range for this recharge history demonstrates the uncertainty in recharge estimates as a result of expected variability in $\mathrm{Cl}$ deposition over time, taking into account effects of both recharge rates and chronology (Figure 7). While most decadal-scale variability is indistinguishable within the $2 \sigma$ range, peaks in the major wet phases are distinct from troughs in the dry phases from AD 1300 to 


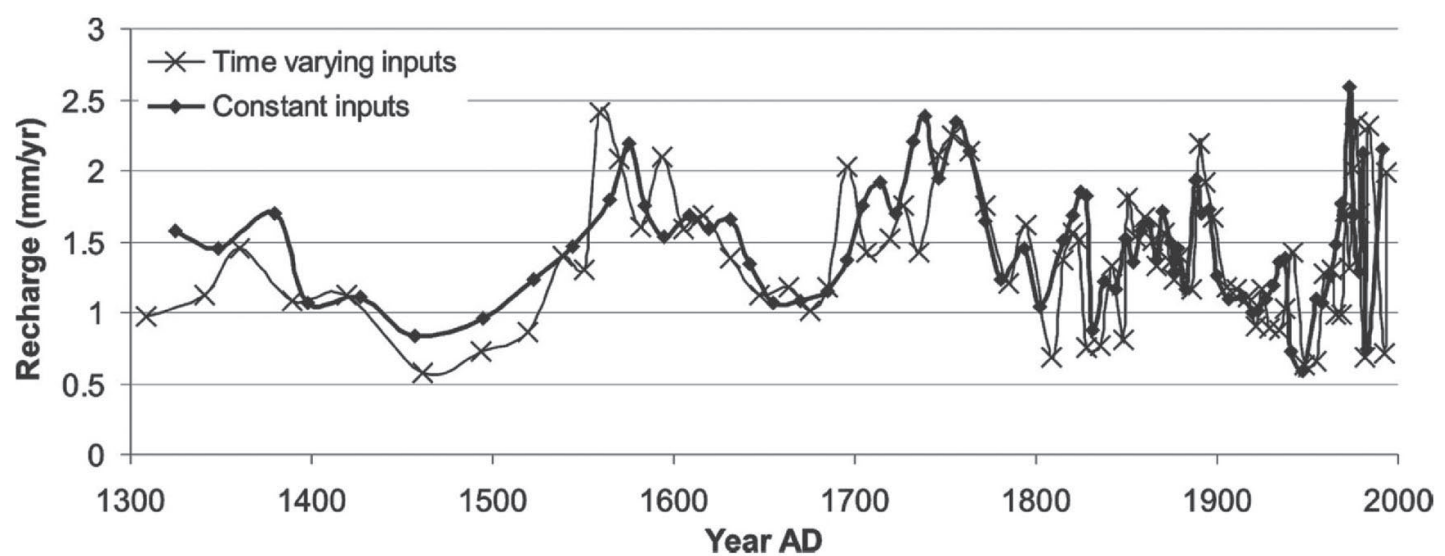

Figure 6. Comparison of constant and time-varying $\mathrm{Cl}$ input scenarios

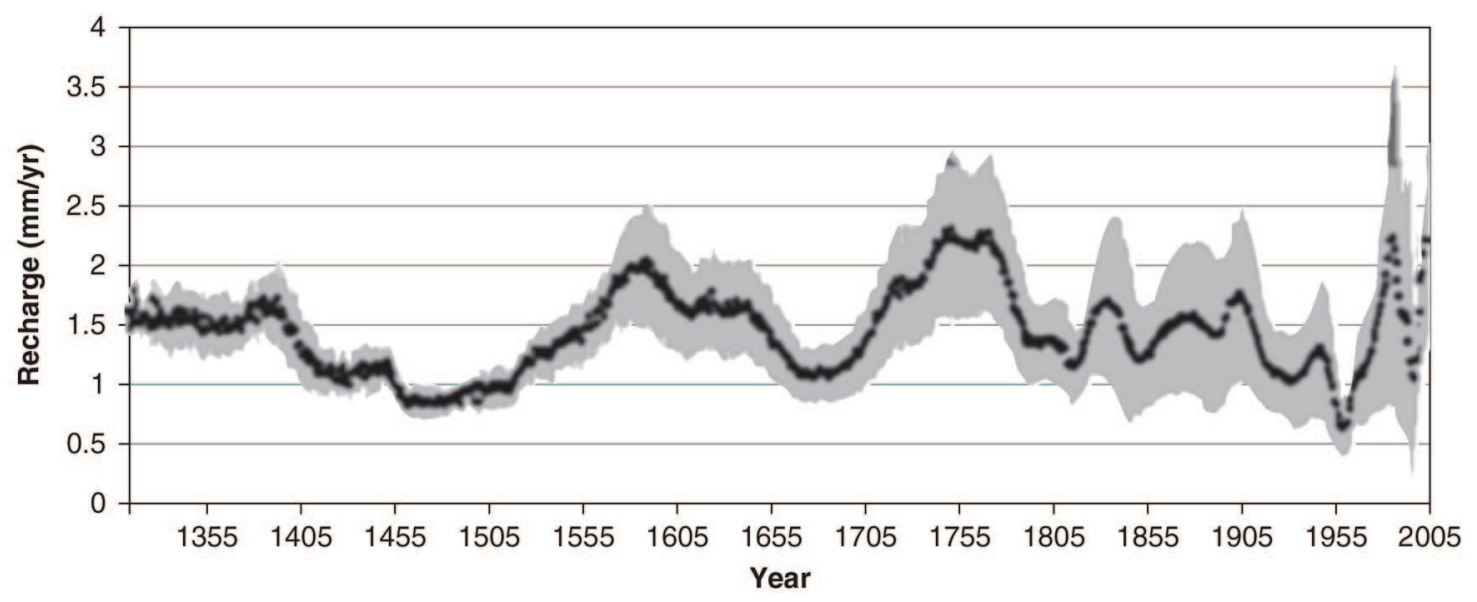

Figure 7. Results of Monte Carlo simulation

present. Margins of error higher from 1700 to 1990 than 1300 to 1700 are a reflection of the higher interannual variability represented in the profile over this period, which itself may reflect a lower degree of mixing and/or the higher sampling density at shallower depths.

The broad correspondence between Badain Jaran recharge rates and precipitation reconstructions from wetter areas of NW China suggest that multidecadal and century-scale climate fluctuations have occurred across the region. However, fluctuations in rainfall rates cannot be derived because of the complexity of recharge/rainfall relationships owing to vegetation changes and other factors and the potential effects of signal smoothing owing to solute mixing. Hence the magnitude of fluctuations in desert rainfall relative to other areas cannot be assessed. If a linear rainfall/recharge relationship (1.7\% based on modern conditions) and negligible mixing were assumed, then maximum and minimum rainfall estimates would be $150 \mathrm{~mm} / \mathrm{yr}$ (1975-1978 and 1731-1738) and $\sim 30 \mathrm{~mm} / \mathrm{yr}$ (1941-1947), respectively, over the 700-yr record.

The inferred relationship between rainfall and recharge contrasts with the situation in the southwestern USA where detailed monitoring studies show that recharge is not highly sensitive to variations in precipitation associated with El NiñoSouthern Oscillation. This has been attributed to vegetation blooms in response to the increased rainfall, and has been hypothesized to be globally widespread based on relationships between satellite-based vegetation indices and precipitation over time (Lotsch et al., 2003; Scanlon et al., 2006). However, response of diffuse recharge rates to major rainfall fluctuations has been inferred in several other arid and semi-arid case studies, e.g., Edmunds et al. (1992) and Edmunds and Walton (1980). In the case of the Badain Jaran, the poor organic content and geomorphologic instability may deter vegetation from responding to elevated precipitation rates.

\section{Conclusion}

Temporal patterns in groundwater infiltration in the Badain Jaran Desert over the past 700 years have been established using $\mathrm{Cl}$ mass balance in multiple unsaturated zone profiles. The major source of uncertainty in such records stems from the difficulty in establishing the solute input function, which was addressed by comparing three hypothetical input scenarios. Clbased recharge histories were compared with other indicators of humidity from ice cores, tree rings, lake sediments, monitoring records and historical documentation. Broad correspondence between the unsaturated zone record and proxies from wetter areas of northwestern China indicate that century-scale humidity trends persist across the region's moisture gradient, and that these variations result in some temporal variability in infiltration. The wettest period on record occurs between 1950 and 1990, similar to the findings for Juniper tree rings in Qinghai Province when low-frequency variation in ring width is fully taken into account (Sheppard et al., 1997).

In the Badain Jaran, because of low infiltration rates, direct recharge through the unsaturated zone is a very minor part in the overall water balance and has negligible impact on levels of groundwater in the shallow Quaternary aquifer, which supports small-scale agriculture and the Badain Jaran's oasis lake system. As such the observed temporal fluctuations 
in recharge (a factor of approximately 3 over the period of record) are not likely to have marked effects on water resources. However, the climate fluctuations that they indicate may have had more significant impacts, including effects on groundwater levels through changes in focused recharge from mountain runoff and evapotranspiration rates of surface water. Loss of vegetation because of increased aridity can also enhance dune mobility, currently a major concern in the area owing to progressive desertification of arable land (Jin and Yan, 2004).

While considerable uncertainties inherent in unsaturated zone chloride-based recharge reconstructions hinder quantitative interpretation of the records in terms of precipitation, the approach has potential to contribute to palaeoenvironmental research in numerous locations worldwide. This is especially the case for arid areas, which are typically the most suitable environments for its application (longer records because of low infiltration rates and deep unsaturated zones), and frequently lack high-resolution palaeoenvironmental archives. Improved monitoring and reconstruction of solute deposition patterns in time and space will further improve the utility of this approach.

\section{Acknowledgments}

The research is supported by the National Science Foundation of China (No. 40671029), the Dudley Stamp grants program of the Royal Society, and the Royal Geographical Society Hong Kong Grant. This work also forms part of a wider UK-China collaboration and we acknowledge the support of the Royal Society through its link scheme (PEK/0992/306). The authors wish to thank Huang Tianming, Zhongqing Nie, and Baojun Zhang for field assistance.

\section{References}

Allison, G.B. and Hughes, M.W. 1978. The use of environmental tritium and chloride to estimate total recharge to an unconfined aquifer. Australian Journal of Soil Sciences 16: 181-195.

An, C., Feng, Z. and Barton, L. 2006. Dry or humid? Mid Holocene humidity changes in arid and semi-arid China. Quaternary Science Reviews 25: 351-361.

Bromley, J., Edmunds, W.M., Fellman, E., Brouwer, J., Gaze, S.R., Sudlow, J. and Taupin, J.D. 1997. Estimation of rainfall inputs and direct recharge to the deep unsaturated zone of southern Niger using the chloride profile method. Journal of Hydrology 188-189: 139-154.

Cook, P.G., Edmunds, W.M. and Gaye, C.B. 1992. Estimating paleorecharge and paleoclimate from unsaturated zone profiles. Water Resources Research 28: 2,721-2,731.

De Vries, J.J., Selaolo, E.T. and Beekman, H.E. 2000. Groundwater recharge in the Kalahari, with reference to paleo-hydrologic conditions. Journal of Hydrology 238: 123.

Dettinger, M.D. 1989. Reconnaissance estimates of natural recharge to desert basins in Nevada, U.S.A., by using chloride balance calculations. Journal of Hydrology 106: 55-78.

Ding, Y. and Chan, J.C.L. 2005. The East Asian summer monsoon: an overview. Meteorology and Atmospheric Physics 89: 117-142.

EANET, Network Center For. 2006. EANET data on the acid deposition in the East Asian region in 2006. Acid Deposition Monitoring Network in East Asia. http://www.eanet.cc/

Edmunds, W.M. and Gaye, C.B. 1994. Estimating the spatial variability of groundwater recharge in the Sahel using chloride. Journal of Hydrology 156: 47-59.

Edmunds, W.M. and Tyler, S.W. 2002. Unsaturated zones as archives of past climates: toward a new proxy for continental regions. Hydrogeology Journal 10: 216-228.

Edmunds, W.M. and Walton, N.R.G. 1980. A geochemical and isotopic approach to recharge evaluation in semi-arid zones, past and present. Arid zone hydrology, investigations with isotope techniques. International Atomic Energy Agency, 47-68.

Edmunds, W.M., Gaye, C.B. and Fontes, J.C. 1992. A record of climatic and environmental change contained in the interstitial waters from the unsaturated zone of northern Senegal. International Symposium on Isotope Techniques in Water Resources Development. International Atomic Energy Agency.

Eriksson, E. and Khunakasem, V. 1969. Chloride concentration in groundwater, recharge rate and rate of deposition of chloride in the Israel Coastal Plain. Journal of Hydrology 7: 178-197.

Feng, Z., An, C. and Wang, H. 2006. Holocene climatic and environmental changes in the arid and semi-arid areas of China: a review. The Holocene 16: 119-130.

Feth, J.H. 1981. Chloride in natural continental water-a review. U.S. Geological Survey Water-Supply Paper 2176.

Gao, Q., Tao, Z., Li, B., Jin, H., Zou, X., Zhang, Y. and Dong, G. 2006. Palaeomonsoon variability in the southern fringe of the Badain Jaran Desert, China, since 130 ka BP. Earth Surface Processes and Landforms 31: 265-283.

Gates, J.B., Edmunds, W.M., Ma, J. and Scanlon, B.R. 2008. Estimating groundwater recharge in a cold desert environment in northern China using chloride. Hydrogeology Journal doi:10.1007/s10040-007-0264-z.

Gaye, C.B. and Edmunds, W.M. 1996. Groundwater recharge estimation using chloride, stable isotopes and tritium profiles in the sands of northwestern Senegal. Environmental Geology 27: 246-251.

Ginn, T.R. and Murphy, E.M. 1997. A transient flux model for convection infiltration: forward and inverse solution for chloride mass balance studies. Water Resources Research 33: 2,065-2,079.

Gong, G. and Hameed, S. 1991. The variation of moisture conditions in China during the last 2000 years. International Journal of Climatology 11: 271-283.

Goni, I.B., Fellman, E. and Edmunds, W.M. 2001. Rainfall geochemistry in the Sahel region of northern Nigeria. Atmospheric Environment 35: 4,331-4,339.

Hameed, S., Yeh, W.M., Li, M.T., Cess, R.D. and Wang, W.C. 1983. An analysis of periodicities in the 1470-1974 Beijing precipitation record. Geophysical Research Letters 6: 436-439.

Hem, J.D. 1985. Study and interpretation of the chemical characteristics of natural water. U.S. Geological Survey Water Supply Paper 2254.

Herzschuh, U., Kürschner, H., Battarbee, R. and Holmes, J. 2006. Desert plant pollen production and a 160-year record of vegetation and climate change on the Alashan Plateau, NW China. Vegetation History and Archaeobotany 15: 181-190.

Jäkel, D. 2002. The importance of dunes for groundwater recharge and storage in China. Zeitschrift fur Geomorphologie Neues Funde, Suppl. Bd. 126: 131-146.

Jin, Y.Q. and Yan, F. 2004. Monitoring sandstorms and desertification in northern China using SSM/I data and Getis statistics. International Journal of Remote Sensing 25: 2,053-2,060.

Jolly, I.D., Cook, P.G., Allison, G.B. and Hughes, M.W. 1989. Simultaneous water and solute movement through an unsaturated soil following an increase in recharge. Journal of Hydrology 111: 391-396.

Joshi, B. and Maule, C. 2000. Simple analytical models for interpretation of environmental tracer profiles in the vadose zone. Hydrological Processes 14: 1,503-1,521.

Kitching, R., Edmunds, W.M., Shearer, T.R. and Walton, N.R.G. 1980. Assessment of recharge to aquifers. Hydrological Sciences Bulletin 25: 217-235.

Lehmann, B.E., Love, A., Purtschert, R., Collon, P., Loosli, H.H., Kutschera, W., Beyerle, U., Aeschbach Hertig, W., Kipfer, R., Frape, S.K., Herczeg, A., Moran, J., Tolstikhin, I.N. and Groning, M. 2003. A comparison of groundwater dating with ${ }^{81} \mathrm{Kr}$, ${ }^{36} \mathrm{Cl}$ and ${ }^{4} \mathrm{He}$ in four wells of the Great Artesian Basin, Australia. Earth and Planetary Science Letters 211: 237-250.

Lin, R. and Wei, K. 2006. Tritium profiles of pore water in the Chinese loess unsaturated zone: implications for estimation of groundwater recharge. Journal of Hydrology 328: 192-199. 
Lotsch, A., Friedl, M.A., Anderson, B.T. and Tucker, C.J. 2003. Coupled vegetation-precipitation variability observed from satellite and climate records. Geophysical Research Letters 30: 1,774, doi:10.1029/2003GL017506.

Ma, J., Ding, L., Jiawu, Z., Edmunds, W.M. and Prudhomme, C. 2003. Groundwater recharge and climatic change during the last 1,000 years from unsaturated zone of SE Badain Jaran Desert. Chinese Science Bulletin 48: 1,469-1,474.

Ma, J. and Edmunds, W.M. 2006. Groundwater and lake evolution in the Badain Jaran desert ecosystem, Inner Mongolia. Hydrogeology Journal 14: 1,231-1,243.

McCord, J.T. and Stephens, D.B. 1987. Lateral moisture flow beneath a sandy hillslope without an apparent impeding layer. Hydrological Processes 1: 225-238.

Nativ, R., Eilan, A., Ofer, D. and Geyh, M. 1995. Water recharge and solute transport through the vadose zone of fractured chalk under desert conditions. Water Resources Research 31: 253-261.

Phillips, F. 1994. Environmental tracers for water movement in desert soils of the American Southwest. Soil Science Society of America Journal 58: 14-24.

Ross, B. 1984. A conceptual model of deep unsaturated zones with negligible recharge. Water Resources Research 20: 1,627-1,629.

Scanlon, B.R. 1991. Evaluation of moisture flux from chloride data in desert soils. Journal of Hydrology 128: 137-156.

Scanlon, B.R. 2000. Uncertainties in estimating water fluxes and residence times using environmental tracers in an arid unsaturated zone. Water Resources Research 36: 395-409.

Scanlon, B.R., Keese, K., Reedy, R.C., Simunek, J. and Andraski, B.J. 2003. Variations in flow and transport in thick desert vadose zones in response to paleoclimatic forcing (0-90 kyr): field measurements, modeling, and uncertainties. Water Resources Research 39: 1,179, doi: 10.1029/2002WR001604.

Scanlon, B.R., Keese, K.E., Flint, A., Flint, L., Gaye, C., Edmunds, W.M. and Simmers, I. 2006. Global synthesis of groundwater recharge in semiarid and arid regions. Hydrological Processes 20: 3,335-3,370.

Selaolo, E., Gieske, A. and Beekman, H. 1994. Chloride deposition and recharge rates for shallow groundwater basins in Botswana. National Conference Publication - Institute of Engineers.

Shao, X., Huang, L., Liu, H., Liang, E., Fang, X. and Wang, L. 2005. Reconstruction of precipitation variation from tree rings in recent 1,000 years in Delingha, Qinghai. Science in China Series D: Earth Sciences 48: 939-949.

Sheppard, P., Holmes, R. and Graumlich, L. 1997. The 'many fragments curse': a special case of the segment length curse. TreeRing Bulletin 54: 1-9.

Sheppard, P., Tarasov, P., Graumlich, L., Heussner, K., Wagner, M., Oesterle, H. and Thompson, L. 2004. Annual precipitation since $515 \mathrm{BC}$ reconstructed from living and fossil juniper growth of northeastern Qinghai Province, China. Climate Dynamics 23: 869-881.
Shi, Q., Chen, F., Zhu, Y. and Madsen, D. 2002. Lake evolution of the terminal area of Shiyang River drainage in arid China since the last glaciation. Quaternary International 93-94: 31-34.

State Meteorological Administration. 1981. Annals of 510 Years Precipitation Record in China. The Meteorological Research Institute.

Thompson, L.G., Mosley-Thompson, E., Davis, M.E., Lin, P.N., Dai, J., Bolzan, J.F. and Yao, T. 1995. A 1,000 year climatic icecore record from the Guliya ice cap, China: its relationship to global climate variability. Annals of Glaciology 21: 175-181.

Thompson, L.G., Yao, T., Davis, M.E., Henderson, K.A., MosleyThompson, E., Lin, P.-N., Beer, J., Synal, H.-A., Cole-Dai, J. and Bolzan, J.F. 1997. Tropical climate instability: the last glacial cycle from a Qinghai-Tibet ice core. Science 276: 1,821-1,825.

Tyler, S.W., Chapman, J.B., Conrad, S.H., Hammermeister, D.P., Blout, D.O., Miller, J.J., Sully, M.J. and Ginanni, J.M. 1996. Soilwater flux in the southern Great Basin, United States: temporal and spatial variations over the last 120,000 years. Water Resources Research 32: 1,481-1,499.

Walvoord, M.A., Phillips, F.M., Tyler, S.W. and Hartsough, P.C. 2002a. Deep arid system hydrodynamics 2. Application to paleohydrologic reconstruction using vadose zone profiles from the northern Mojave Desert. Water Resources Research 38: 1,291, doi:10.1029/2001WR000825.

Walvoord, M.A., Plummer, M.A., Phillips, F.M. and Wolfsberg, A.V. 2002b. Deep arid system hydrodynamics 1. Equilibrium states and response times in thick desert vadose zones. Water Resources Research 38: 1,308, doi:10.1029/2001WR000824.

Yang, X. and Williams, M.A.J. 2003. The ion chemistry of lakes and late Holocene desiccation in the Badain Jaran Desert, Inner Mongolia, China. Catena 51: 45-60.

Yao, T. and Thompson, L. 1991. Trends and features of climatic changes in the past 5,000 years recorded by the Dunde ice core. Annals of Glaciology 16: 21-24.

Zhang, H., Peng, J., Ma, Y., Chen, G., Feng, Z., Li, B., Fan, H., Chang, F., Lei, G. and Wünnemann, B. 2004. Late Quaternary palaeolake levels in Tengger Desert. Palaeogeography, Palaeoclimatology, Palaeoecology 211: 45-58.

Zhang, J. and Crowley, T.J. 1989. Historical climate records in China and reconstruction of past climates. Journal of Climate 2 : 833-849.

Zhang, J., Jin, M., Chen, F., Battarbee, R.W. and Henderson, A.C.G. 2003. High-resolution precipitation variations in the Northeast Tibetan Plateau over the last 800 years documented by sed-iment cores of Qinghai Lake. Chinese Science Bulletin 48: $1,451-1,456$.

Zimmermann, U., Munnich, K.O. and Roether, W. 1967. Downward movement of soil moisture traced by means of hydrogen isotopes. Geophysical Monographs - American Geophysical Union 11: 28-36. 